ESTUDOS LITERÁRIOS 


\section{SEASONS OF STERILITY}

Mail Marques de Azevedo*

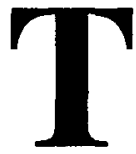

oni Morrison's first novel The bluest eye (1969) depicts with cruel accuracy the victimization of its focus character 11-year-old Pecola Breedlove, the butt of vicious unprovoked attacks by members of her closer communal circles of family and peers, culminating in brutal rape, and of the callous judgment of the community at large. Physical and psychological violence wreaked against Pecola lends The bluest eye the quality of a persecution text - accounts of collective violence - and Pecola's victimization the character of ancient sacrifice. The substitute victim - the scapegoat - is sacrificed in order to restore harmony to the group shaken by internal or external strife. Thus I seek for reflections of communal tension in the natural environment where persecutors and victims - in their condition of natural men, antecedent to that of social men - are inserted. With this aim this paper analyzes initially aspects of the physical environment of the novel and, in the sequence, of the black community of Lorain, the locus of the crisis.

In fact, we observe in The bluest eye vigorous images of destruction, darkness, and sterility which signal turmoil in nature and constitute important clues for the role of nature in the whole process of scapegoating that is central to the novel. Whether considered as causes or reflection of the social crisis that engulfs Pecola these images are seminal for the comprehension of the process.

The novel opens and closes with references to marigolds: "Quiet as it is kept, there were no marigolds in the fall of 1941. We thought at the time, that it

* Universidade Federal do Paraná. 
was because Pecola was having her father's baby that the marigolds did not grow". 'This is the voice of young Claudia, the protagonist's peer and first-person narrator, commenting on her sister's and her own unsuccessful attempts to grow marigolds as a kind of magic ritual to ensure the health and safe delivery of Pecola's baby - the unfortunate product of rape by her own father. Mysteriously there were no marigolds that year, not even in the luxurious gardens of the houses fronting the lake. The narrator's claim that no marigolds bloomed because the earth itself was unyielding - an evident conclusion of adult Claudia who reconstitutes facts from memory - introduces a series of nature images that govern the narrative.

At the close of the novel, Pecola's total destruction is associated with the flowers. Adult Claudia reports Pecola can be seen, even "now", once in a while, "the birdlike gestures [...] worn away to a mere picking and plucking her way between the tire rims, and the sunflowers, between Coke bottles and milkweed, among all the waste and beauty of the world - which is what she herself was"." The juxtaposition of the "waste" and the "beauty" of the world, which pervades the novel, reverses traditional images of growth and fertility into images of decay. The symbolic context of the sacrifice is one extended metaphor of sterility.

The novel's prefatory piece includes both the narrator's childish interpretation and her later mature assessment of the fact: the association of the baby's death with the death of the seeds. In their childish innocence Frieda and Claudia attribute the death of the seeds to their own incompetence: "For years I thought my sister was right: it was my fault. I had planted them too far down in the earth". It is clear to older Claudia, however, that the earth itself had been "unyielding": "What is clear now is that of all of that hope, fear, lust, love, and grief, nothing remains but Pecola and the unyielding earth". ${ }^{3}$

From the locus of the "now" of her adult years, in the final pages, Claudia transfers the guilt for the death of the seeds - which she did not plant too deeply - to "the earth, the land, of our town [...] to the land of the entire country, which was hostile to marigolds that year". ${ }^{4}$

The "land of our town" and "the land of our country" as metaphors for the black community of Lorain, Ohio, and white America in its entirety indicate communal indifference to little black girls who are exiled to the edges of towns

1 MORRISON, Toni. The bluest eye. New York: Washington Square Press, 1972. p. 9.

2 Ibid., p. 159.

3 Ibid., p. 9.

4 Ibid., p. 160. 
and left to wander among refuse and sunflowers, symbolizing utter human misery. Images of natural desolation are, therefore, related to society and culture as a stifling force with no help or compassion strong enough to redeem its members.

Marigolds and sunflowers are the color of gold and, therefore, symbolic of solar light and hence of the divine intelligence, of all that is superior, of spiritual illumination, and of the fruits of the spirit. ${ }^{5}$ They also symbolize the cycles of rebirth of the vegetative force of the earth. By curtailing the cycle of the marigold seeds, which shrivel in sterility, Morrison highlights the signals of the crisis in nature. The symbolic context of Pecola's sacrifice is one extended metaphor of physical and spiritual decay, which places The bluest eye on the level of mythic narrative. Thus, the mysterious sterility of the earth refers us back to the myth of Persephone and Demeter, the ancient Greek goddess in charge of the earth's fertility and its seasons. ${ }^{6}$

Morrison's intention to create an adequate primitive mythical atmosphere for Pecola's sacrificial rites is further evidenced by the division in seasons of the novel's structure. Each chapter has a central unifying idea that is related both to the atmosphere of Pecola's plight and to the symbolism of the season. A cycle of seasons without growth symbolizes the disruption of natural forces, from the "Autumn" of Pecola's sexual maturity to the "Autumn" of her baby's premature birth and death. The reversal from fertility to sterility accompanies Pecola's reversed maturation: the return to babbling infancy-Pecola's schizophrenic dialogues with her imaginary friend - is substituted for the transition into adolescence, whereas shriveled seeds take the place of blooming vegetation.

The ambivalent symbolism of "Autumn", maturity and incipient decay, underlies the beginning of Pecola's story. The little girl's first menstruation signals biological maturity, but is instead a prologue to her sexual violation. Maturity, autumnal harvesting and plenty are negated by the concomitant death of the seeds and of Pecola's baby, at the close of the cycle. Images of darkness, death and fear in Claudia's narrative emphasize the season's chill and decay:

Later we walk home, glancing back to see the great carloads of slag being dumped, red hot and smoking, into the ravine that skirts the steel mill. The dying fire lights the sky with a dull

5 Cf. CIRLOT, J.E. A dictionary of symbols. London: Routledge \& Kegan Paul, 1985. p. $119-120$.

6 VRIES, Ad de. Dictionary of symbols and imagery. Amsterdam : North Holland, 1976. p. 362. 
orange glow. Frieda and I lag behind, staring at the patch of color surrounded by black. It is impossible not to feel a shiver when our feet leave the gravel path and sink into the dead grass in the field. $^{7}$

The passage describes the MacTeers' trips to the railroad tracks to fill burlap sacks with tiny pieces of coal and puts into relief the family's poverty. Autumn is also the season of brown stockings and cod-liver oil and of bronchial tubes packed tight with phlegm.

In the "Spring" chapter, the seasonal symbolism of rebirth is reversed: "The first twigs are thin, green and supple. They bend into a complete circle but will not break. Their delicate showy hopefulness shooting from forsythia and lilac bushes meant only a change in whipping style". ${ }^{8}$ Claudia's memories of the season are shot through with the recollections of the sting left by beatings from thin, green and supple twigs; she misses the "steady stroke of a strap or the firm but honest slap of a hairbrush". ${ }^{9}$ The image of thin, green, "tender" shoots used to inflict pain reaches its major significance in the rape of Pecola by her father, who is said to rape her "tenderly". The incident in spring is preceded by a "false spring" in winter, personified by Maureen Peal, the half-white, green-eyed "dream-child" who rejects Pecola and the two MacTeer girls with a stereotyped insult, "I am cute! And you ugly! Black e mos". "Spring" has ambivalent meanings that mark the contrast between Black and white neighborhoods. There is a gradual change in landscape from the ugliness of the Black part of town - weeds growing through cracks in the sidewalks - to the city park "laid out with rosebuds, fountains, bowling greens, picnic tables, sweetly expectant of clean white well-behaved children and parents". ${ }^{10}$

Signs of rebirth in nature whether taken in their figurative meaning or ironical connotation, thus, symbolize the most painful episodes in Pecola's story. Her cruel rejection by her mother in favor of her white employers' little blond daughter is ironically marked by Claudia's description of the "sundown spilling on the lake". "When Pecola seeks help from the local witch doctor, the parodic Soaphead Church, she is tricked into killing a diseased, mangy old dog whose repulsive sight bothered the old man's fastidiousness. Reversal of images holds

7 MORRISON, p. 12.

8 Jbid., p. 78.

9 Ibid., p. 75.

10 Ibid., p. 84.

11 Ibid., p. 87. 
the central meaning of the chapter, in the figures of the Father-as-protector turned persecutor and of the Mother-as-nurturer transformed into destroyer of her own children.

The scene of the rape is framed by the omniscient narrator's rendering of episodes in the Southern setting of the novel, which acquaint the reader with Cholly's and Pauline's past experiences. The "Spring" of their lives is described in equally powerful natural images that provide the background for their actions in the present of the narrative. The narrator, in the words of George Lipsitz, "looks for the past for the hidden stories excluded from dominant narratives", an action of "counter-memory", ${ }^{12}$ which is consistent with the quasi historical character of The bluest eye.

Claudia's words at the opening of the "Summer" chapter underline the violent character of seasonal storms and the force of the images of seasons which "erupt every way in this book as nature itself remains constant, seemingly aloof, although embodying the essence of memory": ${ }^{13}$

I have only to break into the tightness of a strawberry, and I see summer - its dust and lowering skies. It remains for me a season of storms. The parched days and sticky nights are undistinguished in my mind, but the storms, the violent sudden storms, both frightened and quenched me. But my memory is uncertain; I recall a summer storm in the town where we lived and imagine a summer my mother knew in 1929. There was a tornado that year, she said, that blew away half of south Lorain. I mix up her summer with my own. Biting the strawberry, thinking of storms, I see her. A slim young girl in a pink crepe dress. One hand is on her hip; the other lolls about her thigh - waiting. The wind swoops her up, high above the houses, but she is still standing, hand on hip. Smiling. The anticipation and promise in her lolling hand are not altered by the holocaust. In the summer tornado of 1929 , my mother's hand is unextinguished. She is strong, smiling, and relaxed while the world falls down about her. So much for memory. Public fact becomes private reality, and the seasons of a Midwestern town become the Moirai of our small lives. ${ }^{14}$

12 LIPSITZ, George. Time passages: collective memory and American popular culture. Minneapolis: Un. of Minnesota Press, 1995. p. 213.

13 CHRISTIAN, Barbara. The contemporary fables of Toni Morrison. In: GATES JR., Henry Louis; APPIAH, K.A. (Eds.). Toni Morrison: critical perspectives past and present. New York: Amistad, 1993. p. 63.

14 MORRISON, p. 146. 
I see in the passage much more than a connection with memory. It indicates devastating destruction as the central unifying idea of the chapter, embodied in the violence of nature. The cluster of images of natural elements in fury stand for the violence inflicted on Pecola by the entire community and by the closer social groups of family and peers. Claudia's breaking into "the tightness of a strawberry" brings to mind Cholly's "gigantic thrust into the tightness of [Pecola's] vagina", in the scene of the rape. "Biting the strawberry, thinking of storms, I see her", says Claudia, talking about her mother's experience. It is equally the image Morrison wants the reader to associate with Pecola, that might be worded thus: "Remembering the rape, thinking of the violence of human beings, the reader sees the victim". Morrison's language does in fact provide a powerful context for Pecola's holocaust: lowering of skies, parched days, violent storms that both frightened and quenched, a tornado that blew away half of a town equate the prodigious events in classical persecution texts that signal the loss of social coherence and turn terrified populations to a desperate search for scapegoats.

I read in this passage signs of a text of persecution. The interchangeability between "public fact" and "private reality" is a revealing trait of the scapegoat mechanism. I interpret "public fact" as the need to regain social stability after the destruction wreaked by the disturbance of natural elements or by parallel social upheavals - conflicts of class, race, economic level, and political power -, whereas the "private reality" of each and every one of the members of the community leads him/her to see in Pecola the disturbing element that must be eliminated. The narrator unwittingly reveals the existence of a "real" persecution disguised between the lines, when she uses the term holocaust. The word "scapegoat" - or the idea of victimization - is not articulated openly in relation to Pecola, although her persecutors obviously believe in her guilt, in the same way that medieval populations believed in the guilt of Jews for natural or social upheavals.

The text also indicates Morrison's view of nature as a whole system, complete in itself; nature is a universal entity - public fact - and oblivious to its effect upon man - private reality. Yet, this effect is controlling as the meaning of the Greek word moirai reveals: individual destiny, controlled by the will of the gods. Morrison's representation of summer as the locus of violence ignores ancient Greek symbolism of seasons that represents summer by the figure of a woman wearing a crown of ears of corn, bearing a sheaf in one hand and a sickle in the other. ${ }^{15}$ In Morrison's version summer's characteristic profusion of grain gives way to violent destruction in the physical world and in Pecola's psyche.

15 CIRLOT, J. E. A dictionary of symbols. Transl. Jack Sage. London: Routledge, 1985. p. 282. 
The central image in the "Winter" chapter is the description of $\mathrm{Mr}$. MacTeer's face, a powerful symbol of desolation in nature and its consequence for man. In Claudia's voice:

My daddy's face is a study. Winter moves into it and presides there. His eyes become a cliff of snow threatening to avalanche; his eyebrows bend like Black limbs of leafless trees. His skin takes on the pale, cheerless yellow of winter sun; for a jaw he has the edges of a snowbound field dotted with stubble. His high forehead is the frozen sweep of the Erie, hiding currents of gelid thoughts that eddy in darkness. ${ }^{16}$

Mr. MacTeer's stern expression reflects his concern for the family's survival through winter. We are told he will not "unrazor his lips until spring", a powerful image of the relentless struggle of the Black community.

The violence that in "Summer" gave origin to storm and flood, in "Winter" interrupts the flow of life, but the cycle of seasons moves Pecola inexorably toward victimization. The currents of gelid thoughts under the frozen edges of Mr. MacTeer's forehead are a cogent symbol of hostile, cold undercurrents within the Black community. Morrison's imagery also brings to mind similarities between the phrase "a snowbound field dotted with stubble", that describes Mr. MacTeer's jaw, and the last two lines of Langston Hughes's poem "Dreams":

\author{
Hold fast to dreams \\ For if dreams die \\ Life is a broken-winged bird \\ That cannot fly. \\ Hold fast to dreams \\ For when dreams go \\ Life is a barren field \\ Frozen with snow.
}

The common imagery connotes the domination of a white majority that freezes the spontaneity, the passion, what Morrison calls the "funk" of the black

16 MORRISON, p. 52. 
race. The lyricism of Morrison's description approaches the poignancy of Hughes' protest.

Considerations of setting contrapose the worlds of ideal American middleclass and somber African-American reality. The epigraph to the first chapter, taken from the children's primer that prefaces the novel, highlights the contrast:

\section{HEREISTHEHOUSEITISGREENANDWH ITEITHASAREDDOORITISVERYPRETT YITISVERYPRETTYPRETTYPRETTYP}

In opposition to the utopic view, a pretty green house with a red door, inhabited by happy people, the MacTeers' house is "old, cold, and green", peopled by roaches and mice, whereas the Breedloves live in a storefront, "festering together in the debris of a realtor's dream." The very atmosphere of the homes is somber. Overwhelmed by difficulties, adults are rough in their shows of care. Sick Claudia is called "the biggest fool in town" and rebuked by her mother for her "lack of consideration". Imagery of hope does exist within the family, although in the most minimal form. Adult Claudia comes to recognize the loving care in the touch of her mother's hand on her feverish forehead in the middle of the night, belying Mrs. MacTeer's roughness in daytime. Claudia's father is silent, taciturn, but he is also the protective Vulcan, the keeper of the fires that warm his family.

Pecola's reality is very different. Parent-daughter relationships in her case are destructive, not healing. Where Claudia's father's care for his family makes him instruct the girls about how to "rake, feed, and bank the fire" that will keep the house warm, Cholly Breedlove refuses to comply to his wife's morning request for coal - which gives origin to one of the Breedloves' murderous battles. Pauline Breedlove who rejects her daughter as too ugly to love and is indifferent to her family spends all her energy on her employer's home and children and leaves her own home a cruel, bleak and ugly place. Their storefront is furnished with the minimum necessary items, with "no memories to be cherished".

A common image with different connotations defines the contrasts between the two families. Tending the fire means warmth and security to the MacTeers. Attempts to coax their stove into life on cold mornings spells frustration for the Breedloves. Their stove seems to have independent life, the fire being "out", "banked", or "up" at its own discretion, in spite of all the family's efforts. Like a malevolent deity it rules their lives. It is another example 
of Morrison's irony that Cholly Breedlove sets fire to the family's house, yet has difficulty lighting a fire in his own hearth. The extensive symbolism of fire as creative force, primary element, the essence of life, is denied by the Breedloves' incapacity to keep it going. In ancient Rome, a family's hearth functioned as a shrine for the Lares, gods that protected the homes; it symbolized the union of man and woman, through the conjunction of the fire and its container. It is to be expected that fire should die in an environment that thoroughly subverts its symbolism. The subversion agrees with the contrast established by the epigraph between the Dick-and-Jane myth of familial love, and the bleak reality of incest and rape in the Breedlove household.

Therefore, the scenery of Pecola's plight, whether in its natural or urban environment is adequately desolate and somber. It is as if she were being prepared for her sacrificial role from infancy. The most poignant image associated with Pecola is the description of the girl after the rape, as a "winged but grounded bird": "Elbows bent, hands on shoulders, she flailed her arms like a bird in an eternal, grotesquely futile effort to fly. Beating the air, a winged but grounded bird, intent on the blue void it could not reach - could not even see but which filled the valleys of the mind". ${ }^{17}$ The powerful image represents Pecola's permanent state of inner woundedness, highlighting her otherwise "untranslatable" experiences. ${ }^{18}$

As in Hughes's poem, Pecola's image of a grounded bird signifies the end of her dream:

Hold fast to dreams

For if dreams die

Life is a broken-winged bird

That cannot fly.

The image of Pecola as a grounded bird "intent on the blue void it could not reach" symbolizes the sacrifice of the victim through the destruction of her dream, that is, her desire for the bluest eye, the talisman that would make people love her. The result is the victim's psychic annihilation. Morrison uses images of nature to connote the final sacrifice as a sequence to the earthy images that

17 MORRISON, p. 158.

18 Jacqueline de Weever remarks that specific metaphors from insect and animal life, as used in Black Literature, point to new realities in the growth of personality and character and give the reader access to "untranslatable" experiences (WEEVER, 1991, p. 62). 
depicted the sacrificial crisis. In primitive societies, the need for sacrifice arises from collective misfortune such as famine or the plague. The natural environment of Pecola's sacrifice is equally marked by the infertility of the soil that does not nurture the seeds and by the reversal of the cycle of seasons into ironic and brutal comments of Pecola's descent into madness.

I find it important to revert to myth for parallels to the archetypal situation that Morrison creates in the setting of her novel. Morrison's overt use of myth - Mr. MacTeer is a protective Vulcan - and the analogy to mythological narratives detected in her text lend validity to this approach. Oedipus the king is held responsible for the plague that hits Thebes and is made the scapegoat of the crisis. As René Girard points out, if Sophocles made his tragic hero both king and pharmakos ${ }^{19}$ it is because this relationship is ingrained in the religious practices and social theories of the Greeks, since ancient times. It is the king, an offspring of Zeus, who is responsible for the fertility of the soil, the herds, and the women. If he falters in his duties, the gods visit misfortune on all -limos and loimos, "famine" and "plague". ${ }^{20}$ The king must then be sacrificed, since he is the individual responsible for the collective salvation of the group, or a surrogate victim delegated to assume the role of the unworthy king and be sacrificed in his place.

From the sterility of the soil to the violence of the summer storm, Morrison's treatment of nature points at the holocaust of the victim. Pecola is the surrogate victim that will replace the king, who, in mythical terms, is the responsible for the crisis.

Belief in a union between life and death, the alternation between death and rebirth has long been ascribed to the cycle of seasons. Girard, however, emphasizes that "the periodicity of the seasons serves as an accompaniment to the changes that occur in human relationships and have as their pivot the death of a sacrificial victim". ${ }^{21}$ Death, then, contains the germ of life. There is no life on the communal level that does not originate in death. Consistently, images of death pervade the novel's setting: death in the plant kingdom; the death of the baby; and, finally, holocaust.

Reverting to Morrison's images, we have a picture of the crisis: hidden currents of gelid thoughts eddying in darkness; the unyielding earth of the country;

19 The figure of the scapegoat - a human being called a pharmakos - is still detected in the fifth century B. C., in the Athens of the great tragedians: a victim, maintained by the city at its own expense and slaughtered at the appointed festivals as well as at a moment of civic disaster.

20 GIRARD, René. Violence and the Sacred. 7. ed. Baltimore: The Johns Hopkins Un. Press, 1992. p. 108.

21 Ibid., p. 255. 
the juxtaposition of sunflowers and urban refuse. The significance of the images conducts to the "king", to whom the responsibility of the crisis must be ascribed: the social context which makes victims out of little Black girls, a dominant white class which makes victims out of Black people. The negative images of the Breedloves' storefront home extend to the familial context and, by analogy to the whole community, the condition of pariahs, the social category of the pharmakos.

Morrison herself recognizes that "there are several levels of the pariah figure working in [her] writing. The black community is a pariah community. Black people are pariahs. The civilization of black people that lives apart from but in juxtaposition to other civilizations is a pariah relationship". 22 The seasons of sterility in The bluest eye symbolize the condition of the black community as outsiders to the mainstream culture. The meaning of the "up North" movement, the journey of progress toward a better way of life is deconstructed for the Breedloves and, by extension, for the entire Afro-American ethnic group by the images of sterility - the symbol of virulent unjustified hatred - that pervade the natural environment and the social context of Lorain.

\section{RESUMO}

Este trabalho analisa o locus do romance The bluest eye de Toni Morrison, em busca de sinais da crise social que resulta na vitimização da protagonista.

Palavras-chave: Toni Morrison, The bluest eye de Toni Morrison, análise literária.

\section{ABSTRACT}

This paper analyzes the setting of Toni Morrison's The bluest eye, in order to detect signs of the social crisis that origins the process of victimization of the novel's focal character.

Key words: Toni Morrison, Toni Morrison's The bluest eye, literary analysis.

22 TATE, Claudia. Toni Morrison. In: TAYLOR-GUTHRIE, Danille (Ed.). Conversations with Toni Morrison. Jackson: Un. Press of Mississippi, 1994. p. 168. 


\section{REFERÊNCIAS}

CHRISTIAN, Barbara. The contemporary fables of Toni Morrison. In: GATES JR., Henry Louis ; APPIAH, K.A. (Eds.). Toni Morrison: Critical perspectives past and present. New York: Amistad, 1993. p. 59-99.

CIRLOT, J. E. A dictionary of symbols. Transl. Jack Sage. London : Routledge, 1985.

GIRARD, René. Violence and the Sacred. 7. ed. Baltimore: The Johns Hopkins Un. Press, 1992.

LIPSITZ, George. Time passages: collective memory and American popular culture. Minneapolis: Un. of Minnesota Press, 1995.

MORRISON, Toni. The bluest eye. New York: Washington Square Press, 1972.

TATE, Claudia. Toni Morrison. In: TAYLOR-GUTHRIE, Danille (Ed.). Conversations with Toni Morrison. Jackson: Un. Press of Mississippi, 1994. p. 156-170.

VRIES, Ad de. Dictionary of symbols and imagery. Amsterdam: North Holland, 1976.

WEEVER, Jacqueline de. Mythmaking and metaphor in Black women's fiction. New York: St Martin's Press, 1991. 